IIUC STUDIES

ISSN 1813-7733

Vol.-12 December 2015

(P. 87-100)

\title{
Strengthening the Marginalized from Within: Derek Walcott's Poetic Mission
}

\author{
Md. Abu Saleh Nizam Uddin ${ }^{1}$
}

\begin{abstract}
Caribbean poet Derek Walcott , in his commitment to the Caribbean and, of course, with artistic excellence, disappointingly finds his nation still confined to marginalization which is self-imposed, though it was colonially imposed during the colonial period. The issues contributing to this self-imposed marginalization, an otherwise colonial legacy, are the exigent factors Walcott's relentless poetic efforts address. This paper aims at exploring how Walcott 's unalloyed poetic dedication of epistemological siginificance, with a view to strengthening the Antillean from within, concentrates on the marginalized nation's unconscious, imprudent and self-centred thoughts and measures in the issues of Caribbean self, tourism, urbanization, governance, literary tradition and uniqueness of literature in a post-colonial context of agressive Euro-American economy and culture.
\end{abstract}

Nobel Laureate Derek Walcott's flawless and relentless Caribbean spirit is widely-acclaimed. Preceded and directed by his inseperable bond with ineffable Caribbean root, his substantial preoccupation with the Antillean nature and nation makes him a poet with a mission and a vision. As his magnanimous poetic ability is revealed through his poems, dramas, speeches, lectures and interviews, subtle observation can also make one feel the presence of Walcott 's indomitably robust efforts addressing certain issues prevailing in his Caribbean nation and authority. The issues have left the nation self-marginalized while it is known to all that marginalization was a dehumanizing and inferiorizing process of British Imperialism that had been imposed on the colonized.

The issues Walcott epistemoligically addresses feature through the shattering of the Caribbean self, reckless and servile tourism, unsound urbanization, oppressive and artless authorities , the gross assumption that the Caribbean literary background is absent and finally the writing of unique Caribbean literature is impossible.

\footnotetext{
${ }^{1}$ Assistant Professor, Department of English Language and Literature, International Islamic University Chittagong (IIUC), Chittagong, Bangladesh.
} 
In Peter Onwudinjo and Chris Egharebva's “The Dimension of the Common Man in Derek Walcott's Omeros: An Intertextual Approach", how Walcott, with successful innovative deviation from tradition, makes the common people of the Caribbean the characters of his epic poem Omeros is explored. Sandra Sprayberry, in "Sea Changes: Post-Colonialism in Synge and Walcott", figures out how Walcott's poems imbibe a unique harmonious interplay between Caribbean nature and Western literary tradition. Christopher Lowell Stuck, in his research 'And have not Mercy, I am Waiting: Conscious Inaction as Postcolonial Resistance in Patrick Kavangh's "The Great Hunger" and Derek Walcott's "The Fortunate Traveller"', shows how Walcott in his poetic approach maintains a deliberate inaction in some fields of western hegemony in a Post-colonial world. But no research has been made so far relating Walcott's poetic efforts for the all-out empowerment of the Caribbean nation from inside in a Post-colonial world.

As lecture $\mathbf{s}$ and speeches of a poet set him or her in a more direct position to rethink of their ideas that prompt them to write poems, the article will concentrate chiefly on Walcott's widely discussed Nobel Lecture given in 1992 and interview with Edward Hirsch in The Paris Review published in 1985, both belonging to a more matured and complex post-colonial world where former Euro-colonizers and the USA ponder over the mental hegemony in each individual of the nations of the world in order to cause self-marginalization in them as their territorial occupations do not exist any more. Here are also taken into account some of his poems included in different volumes of his poetry published after the shattering of the Caribbean Federation and independence of island-states like Jamaica, and Trinidad and Tobago in 1962, and during and after the revolt of independence in his motherland Saint Lucia in 1979. The collections of his poems under discussion are The Gulf and Other Poems (1969), The Gulf (1970), Another Life (1973), Sea Grapes (1976), The Star-Apple Kingdom (1979) and The Fortunate Traveller (1981).

Unity of the Caribbean self, deeply rooted in all the Antillean, is of supreme importance to Walcott. In the discussion of the Caribbean self, the issue of unity inevitably comes because the spirit is commonly shared by the people who live in different islands. Walcott never supports the disintegration of the African nation. He cannot bear any more factor of disintegration as there is already the sign of a colossal disintegration in the form of geographical separation of the Caribbean people from their origin in Africa. The geographical separation has broken their history, language and culture into small pieces and they 
strive to accommodate to the new setting relying on those small but strong pieces of their history, language and culture that are still fresh in their memory. Walcott says that due to the split, the Caribbean now have "shipwreck of fragments, these echoes, these shards of a huge tribal vocabulary, these partially remembered customs" though "they are not decayed but strong” (Walcott, 1992).

For this reason, he vehemently opposes the breaking up of the West Indies Federation, though it has happened to his intense grief. The fishermen, the very breath of this spirit, are lifeless now. This extremely tragic event which the poet and others have to face has been the result of some politicians' inordinately commercial thoughts of personal interest. In "Homecoming: Anse La Raye" included in The Gulf and Other Poems (1969), Walcott writes:

dead fishermen move their draughts in shade, crossing, eating their islands,

and one, with a politician's

ignorant, sweet smile, nods,

as if all fate

swayed in his lifted hand. (Walcott,1986: p.129)

Walcott's steadfast standpoint in favour of the unity of the Caribbean self does not only oppose the disintegration of the Federation, it also embraces both the communities - one which has Indian origin and the other which has African - unifying them into one Caribbean nation. Walcott's views may be interpreted by mentioning that the slaves from Africa and other slaves in the form of the indentured tribes from India, that is, Asia, are separate rivers with their own religions and origins in two separate continents. They have boiled down to the same sea called Caribbeanness. The fact that they do have vague memory of their roots is evident as we see that the indentured tribes at the Caribbean village Felicity, with their remembrance of the Hindu myth of Ram, stage the drama called Ramleela in their new Caribbean home. This fact is mentioned by Walcott in his Nobel Lecture. Including both the communities in his lecture, Walcott says,

They are here again, they recur, the faces, corruptible angels, smooth black skins and white eyes huge with an alarming joy, like those of the Asian children of Felicity at Ramleela; two different religions, two different continents, both filling the heart with the pain that is joy. (Walcott, 1992)

Walcott's effort of encouraging good harmonious relationship and unity, not distance or division, between the two communities is remarkable 
here in his probably prudent attempt to stop another possible disintegration of the Caribbean spirit in a post-colonial world.

The reality of this prudence may clearly be understood by looking at colonial Indo-Pak-Bangladesh subcontinent where enmity and conflicts between the two communities - the Hindus and the Muslims were severe permitting the colonizers' divide and rule policy to be considered more and more effective. We are deliberately not mentioning which community played the major role in causing the conflicts in order to avoid digression from the point we are going to make in this article. However, the Poet Kazi Nazrul Islam of Bangla literature understood the horror of division between the two communities and felt the need of unity. In order to inspire amicable and heart-felt ties between them, he held out before them the reality of the same sky under which they lived, and then compared them with two flowers having grown on the same stem. He sings,

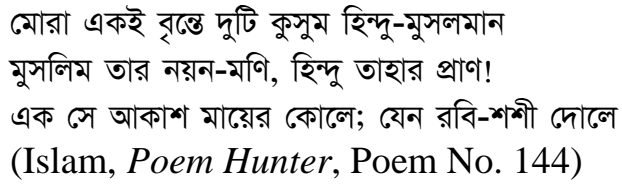

Sazed Kamal translates,

We are two flowers on the same stem - Hindu-Mussulman, Muslims its pearl of the eye, Hindus its life !

In the bosom of the Mother Sky

As if like the Sun and the Moon they swing back and forth;

(Islam, 2000: p. 133)

Satirizing the self-destructive conflicts between the two communities, another poet of Bangla literature Annada Shankar Roy writes, "amra sobai buro khoka”, that is, we are all older children. Roy wants to say that despite being adult, none of the conflicting Indians understands a simple matter that the conflict within the nation will weaken the national unity in the face of British colonial occupation.

Thus, references to the Indo-Pak-Bangladesh subcontinent under the colonial rule and the poet Nazrul provide Walcott's effort a realistic and universal dimension, and the efforts turn out to be forceful to support the unity of the Caribbean spirit.

Walcott cannot remain silent when he sees that the original beauty of the Caribbean nature and the concerned inner vitality of the common people, and culture face jeopardy with the advent of tourism which is reckless, and contains master-slave relationship. 
The poet's heart aches envisaging the destruction of Caribbean nature in the hand of reckless and 'catch-penny' tourism. Far from disallowing such tourism, the Caribbean authorities advertise all over the world the touristic attractions of the islands in a way which is too insulting for the sacred Caribbean spirit. It is nothing but selling off the natural beauty of the Caribbean islands in the name of tourism. Limitless Caribbean nature is reduced to a place of enjoyment for the tourists of rich countries. Walcott says, "But in our tourist brochures the Caribbean is a blue pool into which the republic dangles the extended foot of Florida” (Walcott, 1992).

The tourism also imbibes the impact of the colonial period manifesting the servility of the hosts. Walcott remembers the tourism during colonial rule in the West Indies and finds it to have been servility on the part of the colonized. He says, ". . . servility was a part of the whole deal-the waiters had to smile, and we had to do this and so forth. In tourism, it was just an extension really of master/servant" (Walcott, 2014). Actually, tourism cannot move forward smoothly as it cannot build human relationship when the countries concerned are the colonized and the colonizers. Ngugi wa Thiong'o, the Kenyan dramatist, believes favourable atmosphere is a must for building up human relationships. He says, "They develop in the context of ecology, economics, politics, culture, and psyche" which, being diametrically opposed, cannot develop human relationships between the colonizers and the colonized. (2004).

Even after independence, Walcott despairingly sees the impressions of master-slave relationship persisting in tourism, although it is a good means to expose to the world through the tourists the West Indian culture and heritage. Tourism brings about a needful cultural exchange on the basis of equality. It is bi-lateral, never one-sided. The equal exchange keeps various civilizations alive and in motion towards prosperity.

Walcott's viewpoint is also inherent in Aime Cesaire, the widely-discussed francophone poet, author and politician from Martinique, who opines that cultural exchange occurs on the basis of equality and "that whatever its own particular genius may be, a civilization that withdraws into itself atrophies; that for civilizations, exchange is oxygen” (1972: p. 2). Inequality in post-colonial period emanates from the still dominating western idea of centre and periphery, a hegemonic approach of the colonial period. Europe and America are as important as the centre, and nations of other continents are as dependent and weak as the periphery. To Thiong'o, humanity is the prime centre 
round which all cultures are centers themselves. They move within a circle keeping same distance from the prime centre. They contribute to the principal centre the way it contributes to them. Thiong'o likes the idea. He says, "I like the idea of a dance of centers that are equidistant from the human center. They are in a circle. They all contribute to and also draw from the center” (2004).

Admitting the aggressive external factors as true, Walcott's subtle eyes observe the internal ones. He trenchantly says that the arrangement of tourism in the Caribbean is too poor to utilize the scope of equal cultural exchange. Putting "on steel bands" and having "people in the hotels entertaining" will not suffice. It is rather trivializing. There must be "something more rooted" (Walcott, 2014). And the approach has to be well-organized making arrangement of "a museum", "a good library", places of literary performance and dance, and the like (Walcott, 2014).

But, the state has been an utter failure in providing them. Thus, even in post-independent period, tourism has unpredictably been fruitless. The failure even tends to obliterate the very identity. In "The Virgins" of the volume Sea Grapes, the poet concentrates on Frederiksted, a small locality of the Virgin Islands. Here the poet shows how the cultural agression of the American Dream through tourism has caused the absence of true life, a decline of identity, turning the islands into "the dead streets" (Walcott 1981: p. 70). Disappopintingly enough, Frederiskted is the microcosm of the cultural decline of the greater West Indies.

This tourism that is too rash for capital is almost like free trade for economically weak Caribbean islands in a world of capitalistic giants. This free trade for such a country is termed by the economist and poet Farhad Mazhar as kacha khula (undoing girdle). He opposes the government's inability in exercising its sovereign right over goods and capital and subsequent permission for free trade that turn the state into a market. Metaphorically, the state volantarily undoes its girdle and surrenders everything to foreign goods and capital. The state must understand and play its role to regulate market. It must not think that it is market itself. Mazhar asks, "Can the government be called government any more if it still does not understand the difference between state and market, turns the state into a market and a commodity?” (translation Uddin, p. 140). This viewpoint is also inherent in Walcott's standpoint regarding the Caribbean tourism. 
Obviously, the Caribbean tourism which is a farrago of selfinferiorization and extreme greed is the issue Walcott opposes for the sake of preserving the originality of Caribbean nature, culture and progress.

It is nothing but activities to precede thoughts; the principle the British held up regarding their imperialism. About British Imperialism, K. K. Aziz, the great historian and critic of Euro-Colonialism, views, "By a curious inversion of events action had preceded thought" (1975: p.4). Before it is too late, or as having hindsight of Colonial and PostColonial experiences, Walcott wants to arouse the conscience of the Caribbean to stop veiled self-destruction in the shape of gaudy urbanization. And he shows the way out that will take care of virtue and benefit both. It is eco-friendly as well to facilitate the Caribbean common people to live their normal happy life. In this process, Walcott's frustration is followed by analysis and solution. Here Walcott's poetic effort is to raise awareness in Caribbean governments and people.

Walcott's criticism in his uncompromising campaign for the true freedom of the Caribbean people is ceaseless. During colonial period, he played this vital role by raising voice in favour of independence. Even in post-colonial period, when the islands are independent, he continues to do it by striving for an atmosphere of creativity, freedom of thought and opportunities that allow common people to enjoy their rights. In "Parades, Parades" of Sea Grapes, Walcott has included a disappointing event of Haiti, one of the states of the Caribbean. It is the time after the independence for which desert, ocean and sky are open. But despairingly enough, the government is void of the needful power of imagination.

And the fountain of creativity runs dry. Walcott writes,

so the politicians plod

without imagination, circling

the same sombre garden

with its fountain dry in the forecourt. (Walcott,1981: p. 72)

In this poem, Walcott criticizes the chief of the government "Papa" (Papa Doc is his nick name.) for being despotic as well (1981: p. 73). He observes "the eyes of the beautiful / and unmarked children" which

"widen with terror" when the state arranges Independence Day parades. This "terror" is due to the fanatic nationalism nurtured by the ruler who is called a "fool" (1981: p. 73). As the ruler wants to impose this desire of the state on the individual, a kind of colonial iniquity, Walcott talks in favour of an individual 's freedom of thought. He opines that the state 
must respect the people's rights. As the Haiti government has the tendency to supress the rights of the people, the poet essentially addresses this political injustice.

Ngugi, in a similar context in his country, sees the same terrible flaws in contemporary politics and also in the new generation which neglects the country's history of anti-colonial struggle and a vision full of promises for the nation. He calls the parties involved in contemporary politics as "paper parties" or "regional mafia blocks under a boss" for whom the country is "looters' paradise" (2004)

Walcott realizes the truth that after independence in a postcolonial world, leaders, instead of ensuring the common people's basic needs, express their ulterior motives such as their impatient interest in becoming the President of the country which they regard as a profitable company. Actually, the leaders are like a group of "national bourgeoisie" who enjoyed various key posts during colonial period expressing loyalty to the colonizers. But after independence they face a new scenario. As they still wish to maintain their high positions, they think only money will help them. But the group "possesses neither industrialists nor financiers", and thus they are "underdeveloped bourgeoisie" (Fanon, 1963: p. 98). Therefore, "All its energy is channeled into intermediary activities. Networking and scheming seem to be its underlying vocation" and thus, they find it obligatory to do politics to become the ruler of the country. (Fanon, 1963: p. 98). Clearly, Walcott, not remaining blindly complaisant to regarding the activities of any of the Caribbean governments and people, speaks from the vantage ground of poetry for the welfare and wellbeing of the Caribbean.

Walcott makes the confident declaration that his literature does have its literary tradition in its own way in the history of his early forefathers' Africa. Wayne Brown (1981) considers greatness in Walcott's literature to be something generating entirely from Walcott the individual, and the West Indian literary tradition has no share in it, as it does not exist at all. Brown says,

The ineluctable product of a mind predisposed to obliquity and thrown back on its own resources by the absence of a West Indian literary tradition or any consensus of culture-an educated and embattled mind. (qtd. from "introduction", p. vii)

The British colonizers would opine that the African continent had no history before the colonizers' presence there. It was an imperialistic process of inferiorization of the African indigenous people enabling the colonizers to justify their colonial occupation of the continent. This is 
actually "... justifying African inferiority and British right to rule over the continent" by saying "Africa had no history before colonial rule" (Aziz, 1975: p. 423). Even many academics expressed the same opinion. They would say that prior to the colonizers' arrival into Africa, the continent had only darkness and darkness cannot have any place in history. Hugh Trevor Roper, a professor of History at Oxford, for example, says, “. . . darkness is not the subject of history” (Aziz, 1975: p. 423). Horribly enough, the word "darkness" not only trivializes geographic diversity, but also represents West-produced ethnographic dehumanization of the indigenous Africans.

Africa has its history, and always did, the history of abundant elements and vibrant etymology to give rise to great literature of oral tradition. The type of tradition that the West suggest is not a must for literature and art to collect their elements from. Chinua Achebe even opposed literary tradition that includes literary principles. Achebe says, "Art is, and always was, at the service of men, our ancestors created their myths and told their stories for human purpose" (qtd. in Chowdhury, 2008: p. 148).

Walcott, with robust accuracy, says that his Caribbean islands do have history of African origin which is his literary background, that is, literary tradition. Caribbean islands are actually torn pieces of history, custom and vocabulary from Africa. All he has to do is to put the pieces in right places and construct his Caribbean self that forms his literary background. He says, "Antillean art is this restoration of our shattered histories, our shards of vocabulary, our archipelago becoming a synonym for pieces broken off from the original continent" (Walcott, 1992). Having this history, he can easily avail himself of his literary background as history and culture are closely interconnected. This wisdom is further emphasized by Amilcar Cabral (1973), the twentieth century African scholar of Guinea-Bissau origin, who views that culture from a history is the flower from a plant (p.42). This is how Walcott vindicates his firm footing on his Caribbean identity of African origin in his Nobel Lecture given in 1992. But in 1962 in "A Far Cry From Africa" he wrote about his being in a very shaky stage in a melee relating to his identity. Clearly, $\mathrm{t}$ he dilemma gradually dissipates with the passage of time as he has always looked for his true origin and history. Thus the poet comprehensively removes from himself his confusion, in a sense, ignorance, regarding his Caribbean self.

However, Walcott clearly discerns the literary background, which comes after the African background, as available in the ways Caribbean nature and common people are reshaped in the island environment deriving its 
origin from Africa. Thus, to the making of that literary background, Walcott sees the contributions of the woodcutters, farmers, fishermen, footmen and nature, all pricelessly illiterate. About them, he says,

... hard mahogony of woodcutters . . . the fishermen, the footmen on trucks, groaning up mornes, all fragments of Africa originally but shaped and hardened and rooted now in the island's life, illiterate in the way leaves are illiterate; they do not read, they are there to be read, and if they are read, they create their own literature. (Walcott, 1992)

The background is quite strong and orderly. If the components of that background are not as established as books, theatres, museums etc, there is nothing to be frustrated of, Walcott believes. He mentions that his literary background does contain valuable thought which generates poetry. Proud Walcott declares:

Here there are not enough books, one says, no theatres, no museums, simply not enough to do. Yet, deprived of books, a man must fall back on thought, and out of thought, if he can learn to order it, will come the urge to record, and in extremity, if he has no means of recording, recitation, the ordering of memory which leads to metre, to commemoration. (Walcott, 1992)

In this process the poet revives in him the stories he heard in his childhood about gods, demigods, demons and fairy figures which have always been indelible part of his life and of the community. He also recalls the teachings of and experiences with Caribbean painters Harold Simmons, Dunstan St. Omer and Cezanne. He adds to them Caribbean flora and fauna, slaves and fishermen. Knowing that the original form of poetry is oral which perhaps indicates Homer, he continues his poetic efforts. Some of his best works are in a regional vernacular. The poem "The Spoiler 's Return" from The Fortunate Traveller is such an example which includes the lines "I going to bite them young ladies, partner, / like a hot dog or a hamburger” (Walcott, 1986: p. 432). Here Walcott plays an important role to decolonize his nation by identifying and revivifying native history that was under predatory suppression of the colonizers in the colonial period. Here Walcott is echoed by Edward Said (1994) who opines that foundation for decolonization may be constructed by discovering and re-establishing whatever, belonging to the past of a nation, has been subdued and suppressed by Imperialism (p. 253). 
After unflinching declaration regarding the background of Caribbean literature, Walcott shows how they will go forward upholding unique Caribbean identity. In such effort the issue of language comes first. In his advanced years, he no more deems his attraction to English as something contrary to his Caribbeanness and pinpoints that "The English language is nobody's special property. It is the property of the imagination: it is the property of the language itself" (Walcott, 2014). Thus, English, by not being the property of any particular nation, becomes a universal language, a common property of all nations.

Then, putting one more step forward, Walcott rightly shows how this common property called English can be given a Caribbean individuality. As the Caribbean consist of two races-Indian and African, and are deprived of their original Asian and African languages respectively because of geographical separation and colonial subjugation, there may be a tormenting sense of loss. But Walcott manages to get rid of it. More confident, he firmly believes in the emergence of the Caribbean language that will keep the African and Asian languages as its origin. Walcott says,

Deprived of their original language, the captured and indentured tribes create their own, accreting and secreting fragments of an old, an epic vocabulary, from Asia and from Africa, but to an ancestral, an ecstatic rhythm in the blood that cannot be subdued by slavery or indenture. (Walcott, 1992)

Unique language must have unique literature. When this is the truth, busy Walcott sets out to establish unique Caribbean literature. His poems "Parades, Parades" and "The Wind in the Dooryard" from Sea Grapes are two examples of exclusively Walcottian splendor, as they contain vers libre, his own creation in terms of the construction of metre and rhyme. Making deliberate and courageous deviation from iambic pentameter, the widely used metre of English verse, Walcott introduces vers libre that includes various qualities of prose. Thus, it permits a wide variety of metres and forms making room for the poet to confidently narrate things from objective point of view. Using his glorious vers libre in "Parades, Parades", the Caribbean voice utters,

There's the wide desert, but no one marches except in the pads of old caravans, there is the ocean, but the keels incise the precise, old parallels, there's the blue sea above the mountains but they scratch the same lines in the jet trails- (Walcott, 1981: p. 72) 
Then, Walcott introduces Caribbean individuality in his epic poem Omeros (1990) by selecting characters mostly from Homer's The Iliad and The Odyssey but keeping the setting in Saint Lucia. It is notable indeed that Omeros is the literary piece that earns the Nobel Prize for Walcott recognizing the Caribbean individuality as an important part of his style. To Wayne Brown (1981) "it is also a defining characteristic of his style" ('introduction”, p. ix). This is Walcott's individual style and tireless effort that provide Caribbean literature with individual identity. And this is how Walcott is "making his own tools like Crusoe" keeping its base in the Antillean experience of "shipwreck of fragments, these echoes, these shards of a huge tribal vocabulary, these partially remembered customs, and they are not decayed but strong" (Walcott, 1992). We have already mentioned this Antillean experience which has formed the base of Caribbean literature.

By nature, the West Indian people are such that anything grand or great easily attracts them. That they like "grandeur" and "large gestures" is their predilection. This taste is taken care of by Walcott, and figures of speech, especially metaphor, are used. In "Hawk" from The Gulf, Walcott writes

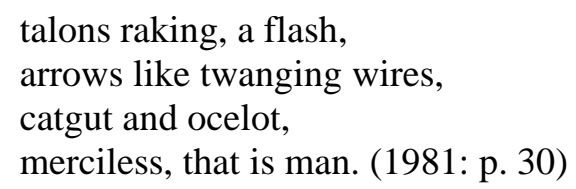

The poet's poetic vehemence is generated as a response to Caribbean taste for the grand and the great. This venture determines the Caribbean archipelago's own literature. Walcott's objective is “.... to find permanent anchorage in a poetry pared to the bone” (Geddes, 1996: p. 456).

French Patois is the vernacular of the Santa Lucian islanders. The poet deplores the loss of this dear mother tongue under the influence of English, the national language. Then, with the objective of keeping the vernacular alive and strong Poet does not feel satisfied simply after disclosing the reason of his pain. He acts. He uses French Patois in parallel with , he uses it in parallel with Caribbean English. "The Schooner's Flight" from The Star-Apple Kingdom (1979) is one of the examples where he writes,

I go draw and knot every line as tight

As ropes in this rigging in simple speech

my common language go be the wind,

my pages the sails of the Schooner Flight.(Walcott,1986:p. 347) 
According to Eliot (1993) a good poet should know "the past should be altered by the present as much as the present is directed by the past” (p. 2171). Walcott, while fulfilling his commitment to his nation, naturally internalizes Eliot's view. However, there is no denying the fact that Walcott does do justice to his identity as a poet by meditating on the past or history of Africa, and then the West Indies and at last his private experience. Finally, he produces literature of Caribbean and individual uniqueness. Here his individual uniqueness is of course pleasantly subordinate to the Caribbean one.

Walcott discovers a teleological link between the purpose of West Indian well-being, and the events and developments that are helpful to achieve the purpose. But the prevailing events and developments are not in accordance with the purpose. They occur owing to the ignorance, indifference and contumacy of the Caribbean in case of their welfare and development, that is, the self-imposed marginalization of the Caribbean. Walcott addresses the obstacles with a view to strengthening the Caribbean from within and having the teleological link fulfil. Thus, in addition to having literary excellences, depicting equally significant nobility at individual, national and universal levels, Walcott passes the final test to be a poet of true value because "The ultimate test of literature, as of all human efforts, is nobility" (Aziz, 1975: p. 168). Walcott accepts for his life a sacred and noble mission to extricate the Caribbean people from their self-imposed marginalization in the face of an ever-aggressive and dominant Euro-American economy and culture in the post-colonial context. 


\section{Works Cited}

AZIZ, K. K. The British in India: A Study in Imperialism . Islamabad, Pakistan: National Commission on Historical and Cultural Research, 1975.

BROWN, WAYNE. ed. Introduction. Selected Poetry-Derek Walcott. Caribbean Writers Series. London: Heinemann, 1981.

CABRAL, AMILCAR. Return to the Sources: Selected Speeches. New York and London: Monthly Review Press, 1973.

CESAIRE, AIME. "Discourse on Colonialism”, Trans. Joan Pinkham, New York and London: Monthly. Review Press, 1972, web. 7 January 2014.

CHOWDHURY, KABIR. "Chinua Achebe", Goethe O Rabindranath Abong Onnanya, Trans. Md. Abu Saleh Nizam Uddin, Dhaka, Bangladesh, Annesha Prokashon, 2008.

ELIOT, T. S. The Norton Anthology of English Literature, ed. M. H. Abrahms, Vol. 2, Sixth edition, New York and London: Norton \& Company, 1993. pp. 2071-2076.

FANON, FRANTZ. The Wretched of the Earth, Trans. Constance Farrington, Trans. Constance Farrington, Grove Press, New York, 1963.

GEDDES, GARY. Ed. "Derek Walcott” $20^{\text {th }}$ Century Poetry and Poetics, Fourth Edition, Oxford University Press: 1996.

ISLAM, KAZI NAZRUL. Poem Hunter, Poem No. 144/165, Web Dec 6, 2016. http://www.poemhunter.com/poem/mora-eki-brinte-duti-kusum-hindu-musalman/

ISLAM, KAZI NAZRUL. Poetry of Kazi Nazrul Islam in English Translation. Trans. by Sajed Kamal, Dhaka: Nazrul Institute, 2000

MAZHAR, FARHAD. Banizza O Bangladesher Janagan: A Collection of Essays, (Trade and the People of Bangladesh), trans. by Md. Abu Saleh Nizam Uddin, Dhaka, Bangladesh: Agamee Prakashani, 2011

ONWUDINJO, PETER and CHRIS EGHAREBVA. "The Dimension of the Common Man in Derek Walcott's Omeros: An Intertextual Approach”,

Lwati: A Journal of Contemporary Research, Vol 9, No 1 (2012).

SAID, EDWARD W. Culture and Imperialism, Vintage, London, 1994.

SPRAYBERRY, SANDRA. "Sea Changes: Post-Colonialism in Synge and Walcott", The South Carolina Review, 1996.

http://www.clemson.edu/cedp/press/scr/articles/scr_33-2_sprayberry.pdf

STUCK, C. L. 'And Have Not Mercy, I Am Waiting: Conscious Inaction as Postcolonial Resistance in Patrick Kavanagh's "The Great Hunger" and Derek Walcott's "The Fortunate Traveller"', (Master's thesis). 2015.

http://scholarcommons.sc.edu/etd/3079

THIONG'O, NGUGI WA. Interview by Michael Pozo, st. John's university humanities review, vol. 2.2 (2004), Web. 20 Feb. 2014. (page no. not mentioned in the internet source)

WALCOTT, DEREK. Selected Poetry -Derek Walcott. ed. Wayne Brown, Caribbean Writers Series. London: Heinemann, 1981.

_ _ _. Collected Poems: 1948-1984, New York: Faber and Faber, 1986. Print.

_ _ - "Nobel Lecture: The Antilles: Fragments of Epic Memory." 7 Dec. 1992. Nobel Prize. org. Nobel Media AB 2013. Web. 18 Feb. 2014. (page no. has not been mentioned by the Nobel Foundation in their official web page)

“The Art of Poetry." No. 37, Interview by Edward Hirsch, the Paris Review, 2014. Web. 15 April, 2014. (Page no. not mentioned in the internet source) 